\title{
Categorization of the Concept of Freedom by the Representatives of Different Information Subcultures
}

\section{Категоризація поняття «свобода» представниками різних інформаційних субкультур}

Elena Medvedskaia

Ph.D. in Psychology, Assistant Professor, Brest State A. S. Pushkin University, Brest (the Republic of Belarus)

ORCID ID: https://orcid.org/0000-0003-2033-510X

Researcher ID: M-4006-2019

E-mail: EMedvedskaja@mail.ru

\section{Слєна Медведская}

Кандидат психологічних наук, доцент, Брестський державний університет імені О. С. Пушкіна, м. Брест (Республіка Білорусь)

\section{ABSTRACT}

The aim of the article is a comparative analysis of a structure and content of the concept "freedom" in the consciousness of adults who prefer different types of information media, traditional printed or new digital.

Methods. The study was carried out on a statistically large and homogeneous sample by age, level of education and professional activity (sphere of Intellectual labour). The differentiation of respondents into different information subculture representatives was carried out on the basis of two criteria: 1) the choice of an information media in their free time (printed media or the Internet); 2) the amount of time devoted to interaction with the chosen carrier. The criteria were determined through anonymous and voluntary questionnaires.

Address for correspondence, e-mail: kpnu_lab_ps@ukr.net Copyright: (C) Medvedskaia Elena

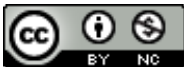

The article is licensed under CC BY-NC 4.0 International

(https://creativecommons.org/licenses/by-nc/4.0/)

(C) Medvedskaia Elena

DOI (article): https://doi.org/10.32626/2227-6246.2020-50.167-187 
DOI: https://doi.org/10.32626/2227-6246.2020-50 2020. випуск 50

To study the structure and content of the concept "freedom» the author's version of the method of semantic differential has been implemented. The author's research method includes descriptors previously obtained by other researchers, on the basis of which, 7 categories ("Assessment», "Strength", "Activity», "Complexity», "Orderliness», "Reality» and "Usuality») of everyday consciousness were extracted.

Results of the research. The results of a comparative analysis carried out in two contrasting groups choosing different information sources: the reading subjects and the active web-users are presented. Statistically, there is no significant difference between the two samples. As a result of a primary processing of the data of the average estimates on the scales of the semantic differential, the profiles coincide in the two groups. As a result of secondary processing (factor analysis), the representatives of different information subcultures revealed the same cognitive complexity of the concept "freedom" (12 factor-categories according to the Kaiser criterion, 4 of which are not accidental in their subjective significance for the respondents) and similar content of the leading categories.

Conclusions. There has empirically been revealed the cognitive simplicity of the "freedom" construct in the everyday consciousness of adult Belarusians and the unity of the representatives of various information subcultures in the understanding of the concept. This cognitive commonality can be explained by the common life experience background, which in the hierarchy of determinants of the content of consciousness turns out to be more authoritative than information habits and, therefore, information itself, regardless of its carrier. The obtained data partially dispel the frightening myth about possible rapid transformations of users' consciousness through digital technologies.

Key words: freedom, ordinary consciousness, categories of consciousness, cognitive complexity, semantic differential.

\section{Introduction}

The concept «freedom» from any point (ordinary, religious, academic) is all-pervasive, interdisciplinary, and multi-dimensional.

The scientific society did not pay much attention to the concept of «freedom». There are quite a limited number of research works, which distinguish two main directions in this field. The pioneers in the research of the concept «freedom" (C) Medvedskaia Elena

DOI (article): https://doi.org/10.32626/2227-6246.2020-50.167-187 
are existentially oriented scientists. Thus, E. Fromm (Fromm, 1990) points out the life-affirming nature of freedom and its ambivalence. He describes in detail the mechanism of a free choice of personality as a step-by-step process that begins with the awareness of "good / bad" and ends up with the desire to act despite the tangible adverse consequences. B. Frankl (Frankl, 1990) interprets freedom as a special position towards both the environment and inner self that gives an opportunity for a change and, moreover, a self-change. Another representative of existential psychology R. May (May, 2016) investigates a similar understanding of the concept. He understands freedom as the awareness of the possibilities within the framework of destiny, as the ability of a person to control himself in the existing objective determinants of life. The theories of subjective causality are the results of another research direction of concept «freedom», based on empirical research data. The most authoritative works in this direction are: a concept of subjectivity of R. Harre (Harre, 1983), which explains the social behaviour of the individual; the studies of self-efficacy as a mechanism for implementing subjectivity of $\mathrm{A}$. Bandura (Bandura, 1997); the theory of self-determination and personal autonomy of E. Dessi and R. Ryan (Deci, Ryan, 1991). In Russian-speaking psychology community, the study of individual freedom has not been a dominant subject for research and is represented by individual works; the most notable studies are published by E. I. Kuzmina (Kuzmina, 1994), G.A. Ball (Ball, 1997), D. O. Leontiev (Leontiev, 2000), and A. S. Belova (Belova, 2008). In the constructive paradigm of psychology, the concept «freedom» is a part of the list of indexed values (Petrenko, 2005), but any research, where «individual freedom» in everyday consciousness is the subject of independent scientific study, has not been found.

The society of the Republic of Belarus at the beginning of the 21st century can be defined as a high-tech society. The

(C) Medvedskaia Elena

DOI (article): https://doi.org/10.32626/2227-6246.2020-50.167-187 
DOI: https://doi.org/10.32626/2227-6246.2020-50 2020. випуск 50

statistics indicate a rapid increase in the number of web users: while in 2016 web users were $66.6 \%$ of the country's population (over 6 years old), the level of web users increased up to $79.1 \%$ in 2018. Regarding the quantity of Internet users from urban and rural areas, the difference is gradually disappearing. The male and female populations have approximately the same web activity. According to the statistics, $80 \%$ are using online services every day, $11 \%$ at least once a week, $9 \%$ do not use the Internet systematically. There is a brief extract (Table 1) from the report of the National Statistical Committee of the Republic of Belarus for 2018 below (Information Society in the Republic of Belarus, 2019: 85). It reflects the prevailing types of web activities of Belarusians (more relevant statistical data are not available at the present moment).

Table 1

Internet users according to the web access purposes in 2018 (as the percentage of the total of Internet users in Belarus)

\begin{tabular}{|l|c|c|c|c|c|c|}
\hline \multirow{2}{*}{ Web Access Purpose } & \multicolumn{6}{|c|}{ Web users according to the age group } \\
\cline { 2 - 7 } & $\mathbf{6 - 1 5}$ & $\mathbf{1 6 - 2 4}$ & $\mathbf{2 5 - 5 4}$ & $\mathbf{5 5 - 6 4}$ & $>\mathbf{6 5}$ & Total \\
\hline Web Search & 79.5 & 98.7 & $\mathbf{9 7 . 0}$ & $\mathbf{9 3 . 5}$ & 86.6 & 93.7 \\
\hline $\begin{array}{l}\text { Watching movies, liste- } \\
\text { ning to the music online, } \\
\text { downloading entertain- } \\
\text { ment files etc. }\end{array}$ & 89.5 & 97.6 & 88.4 & 76.4 & 60.4 & 86.4 \\
\hline $\begin{array}{l}\text { Communication in Social } \\
\text { Network }\end{array}$ & 65.6 & 96.8 & 84.7 & 71.3 & 62.7 & 80.2 \\
\hline
\end{tabular}

The data in Table 1 show that the most popular purpose for users of different age groups is web search. Thus, the majority of Belarusians devote a certain amount of time to Internet surfing on a daily basis, however, the quantitative data do not allow to make a specific conclusion. The data from the table is also not enough to conclude what way this activity affects the consciousness of the active Internet users. 
The views of specialists, including the specialists in the IT industry, on this issue, are quite contradictory.

The ideologists of digital technologies assert positive tendencies. One of them, the American publisher T. O'Reilly (O'Reilly, 2018) draws direct parallels between the interactivity of new media, decentralization of information sources and democratization of both society in general, and the democratization of the consciousness of an individual user.

The thesis of another point refers to high-tech opportunities as well. With the advent of personalized search, an unspoken revolution took place in the digital sphere, it has changed the nature of information consumption. American Internet activist E. Pariser describes it as follows: "Many people think when we google certain words, we all get the same results, we get the pages that the famous Google PageRank consider as the most authoritative, the ranking is based on the links on other pages. However, since December 2009 this has not been the case. Now you see the result, which, according to the Google algorithm, is optimal personally for you. Another person may see something completely different. In other words, there is no standard Google anymore» (Parizer, 2012: 12). Parizer asserts, nowadays, the network is a huge business industry, engaged in the race for personal data: «Share an article on a culinary topic on Facebook and you will be haunted all over the Internet by the ads of saucepans ... The new Internet does not just know that you are a dog, he knows your breed and wants to sell you a bowl of premium dry food» (Parizer, 2012: 12). Thus, the freedom and web personalization are rather ephemeral characteristics, since both the mechanism for extracting personal data and the mechanism of data selection, based on the received personal data, work very effectively. Altogether, according to the metaphorical expression of E. Pariser, it creates a «filter bubble» that just deprives a person of the freedom to search for information, leaving him within the framework of his own interests, views, etc.

(C) Medvedskaia Elena

DOI (article): https://doi.org/10.32626/2227-6246.2020-50.167-187 
DOI: https://doi.org/10.32626/2227-6246.2020-50

2020. випуск 50

A digital revolutionary J. Lanier (Lanier, 2019) adheres to a similar opinion. According to his figurative expression, people that are tied to the web are like dogs that respond to whistling. He encourages users to become cats, to acquire self-sufficiency and independence of thinking. J. Lanier presents a number of arguments that prove the manipulation of consciousness and the imperceptible control of the behavior of the web users, primarily carried out through social networks and search engines. There is a list of a few of them:

- free will loss, gratification addiction (likes);

- brusque intervention in private life;

- aggressive information imposition;

- switch of a person from an «individual» mode to the «pack» mode, which cause the prevalence of cyberbullying phenomenon;

- falsity of information: the creation of a content, motivated by pursuing likes rather than the declared seek for truth;

- lack of empathy in virtual conversation, the inability to influence an interlocutor's context of message perception;

- world perception formation: algorithms demonstrate either what corresponds to the user's views, or what completely contradicts them (thus, solving the problem of keeping the attention). For a different person the programs calculate different information results;

- social networks make people feel miserable. Since this is a race for consumer attention, it is negative experiences that guarantee maximum involvement;

- name and identity loss: a person is defined by the figures (followers, likes, shares, etc.).

At the moment, the views on the possible impact of the Internet on the user's consciousness mentioned above are hypothetical. In the context of cognitive psychology, two main ideas can be extracted from these assumptions. On the one hand, the interactivity of new media makes the consciousness of users more flexible and complex, it leads to the complication (C) Medvedskaia Elena

DOI (article): https://doi.org/10.32626/2227-6246.2020-50.167-187 
of a user's categorical structure. On the other hand, the personalization of web search results restricts and simplifies the categorical structure of a user's consciousness.

The research aim is to prove empirically the hypotheses mentioned above on the basis of one common concept - freedom. This concept is familiar to everyone and has many options for representation in the experience of an individual. One of these options is a personal choice of information media. Different media have different characteristics, use different information coding systems, and users in an overall information culture form two poles: printed and digital subcultures.

\section{Research objective}

The article presents a comparative analysis of the structure and content of the concept «freedom» in the consciousness of adults who prefer different information media: traditional printed and new digital.

\section{Research methods and methodology}

The study (voluntarily and anonymously) involved 720 respondents aged from 37 to 62, including 402 female and 318 male. All research participants have a higher education and are representatives of intellectual labor (teachers, doctors, economists, lawyers). Thus, the sample is homogeneous in two dimensions. First, by age and type of socialization, the main stages of which were completed by all respondents in the pre-digital era. Secondly, by the nature of the daily professional use of various information media (both printed and digital). The data has been collected during 2019 and the beginning of 2020 .

An author of the article used a questionnaire with open questions, in order to study the personal preferences of adults in their choice of information media. The main questions were as follows: the choice of the leading information carrier (printed media or the Internet) in their free time. Secondly, the 
amount of free time devoted to the activities with this system.

The processing of the survey data showed that in the sample $15 \%$ of the respondents (108 people) are adherents of a traditional book as an information media. The representatives of this group choose a traditional source of reading for various reasons: it develops thinking, speech, memory, enriches vocabulary, captivates, etc. They note not only physical discomfort from reading at the screen (eye fatigue, motion sickness), but also relatively worse information assimilation. In what follows, this group will be referred to as «the reading subjects» (or representatives of the traditional printed subculture).

$35 \%$ (252 people) of respondents choose new digital media. The respondents explain their choice by the greater accessibility of the content, its compactness, the concise presentation of the material. When referring to the printed text (especially a book), the respondents note the need for higher concentration, difficulty in access to the information, experiencing boredom or anxiety. In what follows, this group will be referred to as "the active web users» (or representatives of the digital subculture).

The majority of the sample (360 respondents) are respondents who do not have any unambiguous priorities in the choice of information media. These people both read books and use digital media in equal proportions. In order to carry out the claimed comparative analysis by the method of contrasting groups, the results of the representatives of this group are excluded for processing and discussion.

To study the structure and content of the concept «freedom» in the consciousness of adults, the method of the semantic differential in the author's version has been implemented. The decision to set up an author's version has been dictated by the fact that there is no universal set of descriptors as the creator of this method C. Osgood and other scientists have repeatedly mentioned (Osgood, Suci \& Tannenbaum, 1957; Petrenko, 2005; Shmelev, 1982, etc.).

(C) Medvedskaia Elena

DOI (article): https://doi.org/10.32626/2227-6246.2020-50.167-187 
DOI: https://doi.org/10.32626/2227-6246.2020-50 2020. випуск 50

In the present study, there are 40 scales, used as experimental material for a variant of the semantic differential. The purpose of the selection was primarily aimed at controlling the subjectivity of the researcher. The subjectivity is expressed in the possibility of imposing the researcher's own vocabulary on the respondents. Therefore, in order to reduce these risks, 16 adjectives, presented in the classical subject differential by E. Yu. Artemieva (Artemieva, 1980: 37) and 24 adjectives obtained in a large-scale study by V. F. Petrenko (Petrenko, 2005) were used. This study partially repeated the study of C. Osgood and his colleagues (Osgood, Suci, Tannenbaum, 1957-1969), P. Bentler, and A. Lavoie (Bentler \& LaVoie, 1972), and represented a scaling of 50 concepts from different semantic classes on 45 scales of semantic differential. As a result, in addition to the classical factors "Assessment», «Strength», "Activity», factors similar to those obtained by Bentler and Lavoie ( "Complexity», "Stability», "Reality» and «Usuality») were reproduced, as well as the specific evaluative factor «Comfort» (Petrenko, 2005: 91-97).

Secondly, the composition of descriptors for each category was balanced quantitatively, constituting 7-8 adjectives for the universal factors «Assessment», «Strength» and «Activity», and 4-5 adjectives for other factors. They are presented in Table 2.

Thirdly, to have more freedom in a projection of the cognitive structures of the subjects on the experimental material, unipolar scales were set up. It allows to single out synonymy and antonymy of the subject in terms of the described features, which does not necessarily coincide with the normative-linguistic scale (Petrenko, 2005: 206).

The task for the respondents was to evaluate several objects and abstract concepts, including the concept of «freedom» on the presented scales of the semantic differential on a 7 -point scale (from 1 to 7 ).

(C) Medvedskaia Elena

DOI (article): https://doi.org/10.32626/2227-6246.2020-50.167-187 
Descriptors that Form Semantic Differential Categories

\begin{tabular}{|l|l|}
\hline \multicolumn{1}{|c|}{ Category } & \multicolumn{1}{|c|}{ Descriptors } \\
\hline Assessment & $\begin{array}{l}\text { Kind, beautiful, pleasant, clean, bitter, miserable, } \\
\text { disgusting }\end{array}$ \\
\hline Strength & $\begin{array}{l}\text { Massive, young, solid, strong, brave, firm, } \\
\text { intelligent }\end{array}$ \\
\hline Activity & $\begin{array}{l}\text { Active, fast, hot, lightweight, monotonous, full, } \\
\text { vigorous }\end{array}$ \\
\hline Complexity & Singular, simple, constructed, mysterious \\
\hline $\begin{array}{l}\text { Orderliness } \\
\text { Stability }\end{array}$ & Lasting, volatile, organized, accurate, universal \\
\hline Reality & Abstract, accessible, useful, obvious, fantastic \\
\hline Usuality & Banal, exciting, creative, new, rare \\
\hline
\end{tabular}

The means of processing of data obtained with the semantic differential were the factor analysis. The modeling of the categorical structure of the concept «freedom», a similarity matrix of descriptors has been constructed, when evaluating one object separately for different experimental groups (40 scales per 100 subjects). Then the original matrices (8 in total) went through the factor analysis procedure. The factor analysis has been carried out using the procedure adopted in psychosemantics (Petrenko, 2005: 91, 98, 191, 225): the centroid method with the extraction of principal components, including the varimax subroutine for turning factor structures (SPSS v. 16 program). The factors were formed only by those descriptors which load had a high degree of statistical significance (for 40 variables, $r=0.4$ at $\mathrm{p} \leq 0.01$ ). A qualitative interpretation of the data obtained was carried out on the basis of the categories that formed the basis of the semantic differential. 


\section{Results and discussion}

The construction of a profile of the average estimates for two samples for «the reading subjects» and «the active web users" showed that the results are statistically identical $(t=0.14$ at critical $t=2.02$ for $p \leq 0.05)$. Table 3 depicts the descriptors that received the highest marks in different groups of respondents.

Table 3

Maximum assessments of the concept «freedom» among representatives of different information subcultures

\begin{tabular}{|c|c|c|c|c|}
\hline \multirow{2}{*}{ № } & \multicolumn{4}{|c|}{ Respondent Groups } \\
\cline { 2 - 5 } & \multicolumn{2}{|c|}{ The reading subject } & \multicolumn{2}{c|}{ The active web user } \\
\hline 1 & Pleasant & 5.45 & Pleasant & 5.41 \\
\hline 2 & Beautiful & 5.35 & Useful & 5.38 \\
\hline 3 & Lightweight & 5.21 & Beautiful & 5.09 \\
\hline 4 & Kind & 5.17 & Active & 5.02 \\
\hline 5 & Vigorous & 5.09 & Vigorous & 4.89 \\
\hline 6 & Clean & 5.04 & Brave & 4.83 \\
\hline 7 & Lasting & 4.89 & $\begin{array}{c}\text { Strong } \\
\text { Lasting }\end{array}$ & 4.73 \\
\hline
\end{tabular}

The data in Table 3 demonstrate the commonality of assessments in different groups of respondents in a number of categories such as: assessment (pleasant, beautiful), activity (vigorous), and orderliness (lasting). Whereas, in the reading subjects group a positive assessment (kind, clean) and activity (easy) dominate, in the group of the active web users the emphasis is on the parameter of strength (brave, strong) and reality (useful).

Table 4 contains those descriptors that received the lowest average marks in different groups of respondents. 
Minimum assessments of the concept «freedom» among representatives of different information subcultures

\begin{tabular}{|c|c|c|c|c|}
\hline \multirow{2}{*}{ № } & \multicolumn{4}{|c|}{ Respondent Groups } \\
\cline { 2 - 5 } & \multicolumn{2}{|c|}{ The reading subject } & \multicolumn{2}{c|}{ The active web user } \\
\hline 1 & Disgusting & 2.21 & Disgusting & 1.91 \\
\hline 2 & Monotonous & 2.52 & Stupid & 2.36 \\
\hline 3 & Banal & 2.63 & Miserable & 2.56 \\
\hline 4 & Miserable & 2.73 & Monotonous & 2.79 \\
\hline 5 & Stupid & 2.75 & Old & 3.16 \\
\hline 6 & Constructed & 3.08 & Massive & 3.27 \\
\hline 7 & Simple & 3.26 & Constructed & 3.28 \\
\hline
\end{tabular}

The processing results, reflected in Table 4, show the commonality of the respondents' assessments across a range of categories: assessment (disgusting, miserable), strength (stupid), activity (monotonous), and complexity (constructed). Differences in minimum scores between different groups are insignificant and relate to only two positions out of seven. According to the opinion of the reading subjects, "freedom" is not characterized by simplicity and banality, and according to the active web users, "freedom» is not characterized by old age and massiveness.

Thus, the greatest polarization of assessments of «freedom» between the two groups is expressed in the following categories: "Assessment» (pleasant - disgusting, beautiful miserable) and "Activity» (vigorous - monotonous).

As a result of the factor analysis in the two groups of respondents, 12 factors were identified that are significant according to the Kaiser criterion. Since most of them describe a very low percentage of the total variance, for further analysis it seems appropriate to leave only the leading valence factorscategories. Factors exceeding the 5\% randomness threshold (C) Medvedskaia Elena

DOI (article): https://doi.org/10.32626/2227-6246.2020-50.167-187 
DOI: https://doi.org/10.32626/2227-6246.2020-50 2020. ВипУСК 50

in terms of the explained spread of values were also found to be the same number in different samples. For the convenience of comparative analysis, the results of factorization are represented in Table 5. In this table, next to the name of the factor, the percentage of its variance is presented, next to the descriptor is its weight by the factor (only statistically significant loads are reflected that exceed $\mathrm{r}=0.4$ for $\mathrm{p} \leq 0.01$ ).

Table 5

The categorical structure of the concept «freedom» among representatives of different information subcultures

\begin{tabular}{|c|c|c|c|c|}
\hline № & \multirow{2}{*}{\multicolumn{2}{|c|}{$\begin{array}{c}\text { The reading subjects } \\
\text { Strength }+ \text { Activity } \\
(18.17 \%)\end{array}$}} & \multirow{2}{*}{\multicolumn{2}{|c|}{$\begin{array}{c}\text { The active web users } \\
\text { Activity }+ \text { Assessment }+ \\
\text { Strength } \\
(24.96 \%)\end{array}$}} \\
\hline \multirow[t]{12}{*}{1} & & & & \\
\hline & Exciting & 0.797 & Vigorous & 0.804 \\
\hline & Brave & 0.796 & Creative & 0.757 \\
\hline & Active & 0.723 & Pleasant & 0.714 \\
\hline & Vigorous & 0.677 & Beautiful & 0.699 \\
\hline & Strong & 0.559 & Brave & 0.692 \\
\hline & Creative & 0.424 & Exciting & 0.677 \\
\hline & & & Strong & 0.633 \\
\hline & & & Kind & 0.543 \\
\hline & & & Active & 0.491 \\
\hline & & & Useful & 0.461 \\
\hline & & & Clean & 0.444 \\
\hline 2 & \multicolumn{2}{|c|}{$\begin{array}{c}\text { Complexity }+ \text { Reality } \\
(13.69 \%) \\
\end{array}$} & \multicolumn{2}{|c|}{$\begin{array}{c}\text { Orderliness }+ \text { Strength } \\
(\mathbf{1 0 . 4 4} \%)\end{array}$} \\
\hline & Simple & 0.741 & Accurate & 0.817 \\
\hline & Abstract & 0.717 & Organized & 0.803 \\
\hline & Obvious & 0.628 & Massive & 0.639 \\
\hline & Constructed & 0.598 & New & 0.500 \\
\hline & Miserable & 0.507 & Firm & 0.478 \\
\hline & Disgusting & 0.500 & Mysterious & 0.464 \\
\hline & Fast & 0.470 & & \\
\hline & New & 0.404 & & \\
\hline
\end{tabular}

(C) Medvedskaia Elena 
DOI: https://doi.org/10.32626/2227-6246.2020-50

\begin{tabular}{|c|c|c|c|c|}
\hline \multirow[t]{7}{*}{3} & \multicolumn{2}{|c|}{$\begin{array}{c}\text { Assessment } \\
(6.05 \%)\end{array}$} & \multicolumn{2}{|c|}{$\begin{array}{l}\text { Reality } \\
(6.11 \%)\end{array}$} \\
\hline & Useful & 0.696 & Obvious & 0.745 \\
\hline & Kind & 0.656 & Full & 0.624 \\
\hline & Pleasant & 0.615 & Fantastic & 0.568 \\
\hline & Clean & 0.474 & Banal & 0.502 \\
\hline & Beautiful & 0.466 & & \\
\hline & Disgusting & -0.409 & & \\
\hline \multirow[t]{6}{*}{4} & \multicolumn{2}{|c|}{$\begin{array}{c}\text { Orderliness } \\
(5.51 \%)\end{array}$} & \multicolumn{2}{|c|}{$\begin{array}{l}\text { Complexity } \\
(5.09 \%)\end{array}$} \\
\hline & Lightweight & 0.691 & Simple & 0.613 \\
\hline & Organized & 0.683 & Constructed & 0.553 \\
\hline & Beautiful & 0.648 & Stupid & 0.479 \\
\hline & Singular & 0.560 & Monotonous & 0.462 \\
\hline & Banal & 0.449 & Universal & 0.432 \\
\hline
\end{tabular}

The data in Table 5 indicate that the two samples are largely identical not only in the categorical structure of the concept "freedom», but also in the content of the categories. This fact is particularly distinct in the leading category, a combination of two classic factors «strength + activity». This category is richer in terms of assessment descriptors in the active web users group.

The second most valence factor in both groups also represents a combination of several categories ( «complexity + realism» in the reading subjects group, and a semantically similar category of "ordering + strength» in the active web users group). The remaining categories are rather homogeneous in their composition and are not essential in subjective significance, as they barely exceeded the threshold of randomness, thus, they do not require any additional comments.

Only a category "Assessment», represented by the dichotomy "useful - disgusting» in the reading subjects group, is a cognitively complex construction according to its structure. The rest of the categories are unipolar entities.

(C) Medvedskaia Elena

DOI (article): https://doi.org/10.32626/2227-6246.2020-50.167-187 
According to the data presented in Table 5, the categorical structure of the concept «freedom» in the consciousness of the respondents is not distinguished by a great cognitive complexity regardless of the type of information carrier, printed or digital. In fact, two categories out of seven possible, immanently embedded in the semantic differential, were pointed out, which are of significant importance for the respondents. The data of the two groups can also be considered as material for the psychometric technique «splitting the sample in half». As the statistically significant differences neither when comparing the primary estimates, nor when comparing the number of forming categories obtained, has been detected, it is possible to extrapolate the results on the population of the Belarusian intelligentsia.

The revealed cognitive simplicity of the concept «freedom» can be explained by a rather limited experience of Belarusians in exercising freedom (except everyday freedom), since life was carried out under the state system, adherent to the Soviet rigidly centralized administrative-command system. In fact, all this time the population of the state has existed and operated in a system of «negative reinforcement», which reached its climax with the violent suppression of peaceful actions. It appears that the pre-election and especially the post-election events of 2020 have become a determinant that affected the ideas of Belarusians about personal freedom significantly. These changes can be the subject of further study of the categorization of the concept «freedom» in everyday consciousness. From a scientific point of view, such empirical results are of particular interest, since they will determine the possible rate of transformation of basic social attitudes.

\section{Conclusion}

Emotional-evaluative ideas about freedom, revealed among representatives of different information subcultures, turned

(C) Medvedskaia Elena

DOI (article): https://doi.org/10.32626/2227-6246.2020-50.167-187 
out to be statistically identical. The core of ideas of the Belarusians about freedom is its understanding as some unconditionally positive force with a certain orderliness. At the same time, the reading subjects stress out a more pronounced positive evaluative valence of freedom, while among the active web users the accent is on the awareness of its power.

The categorical structure of the concept «freedom" in the consciousness of representatives of different information subcultures has the same complexity and similar content. Its semantic core is expressed in the following categories: "Assessment», «Activity», «Strength», «Complexity», «Reality», which are slightly differentiated in consciousness and merged into two leading factors. According to its content, freedom is presented as a positive, creative energy and force, which corresponds to the general philosophical interpretation of the concept «freedom».

The absence of significant differences between the representatives of the two groups can be explained by the common background of Belarusians in terms of the practical implementation of individual freedom. According to the research results, this fact dominates over information habits, i.e. the use of digital media has little effect on the users' understanding of freedom as a specific concept.

\section{Literature}

Артемьева Е. Ю. Психология субъективной семантики. Москва : МГУ, 1980. $128 \mathrm{c}$.

Балл Г. А. Психологическое содержание личностной свободы: сущность

и составляющие. Психологический журнал. 1997. Т. 18. № 5. C. $7-19$.

Белова А. С. Проблема свободы в психологии: методический аспект. Педагогика и психология. 2008. № 1. С. 129-132.

Информационное общество в Республике Беларусь. 2019. Минск : Национальный статистический комитет Республики Беларусь, 2019. $100 \mathrm{c}$.

Кузьмина Е. И. Психология свободы. Москва : МГУ, 1994. 195 с.

(C) Medvedskaia Elena

DOI (article): https://doi.org/10.32626/2227-6246.2020-50.167-187 
Ланье Дж. 10 аргументов удалить все свои аккаунты в социальных сетях. Москва : Эксмо, 2019. 192 с.

Леонтьев Д. А. Психология свободы: к постановке проблемы самодетерминации личности. Психологический журнал. 2000. Т. 21. № 1. C. $15-25$.

Мэй Р. Человек в поисках себя. Москва : Институт общегуманитарных исследований, 2016. 225 с.

O’Рейли Т. Что такое Веб 2.0? URL : http://www.computerra.ru/ think/234100/.

Паризер Э. За стеной фильтров. Что Интернет скрывает от вас? Москва : Альпина Бизнес Букс, 2012. 304 с.

Петренко В. Ф. Основы психосемантики. Санкт-Петербург : Питер, 2005. 480 c.

Франкл В. Человек в поисках смысла. Москва : Прогресс, 1990. 368 с.

Фромм Э. Бегство от свободы. Москва : Прогресс, 1990. 269 с.

Шмелев А. Г. Об устойчивости факторной структуры личностного семантического дифференциала. Вестник МГУ. Сер. 14. Психология. 1982. № 2. C. $62-65$.

Bandura, A. (1997). Self-efficacy: the exercise of control. New York : W. H. Freeman \& Co. 603 p.

Bentler, P. M., \& LaVoie A. L. (1972). An Extension of semantic Space. Journal of Verbal Learning and Verbal Behaviour. Vol. 109. P. 123144.

Deci, E., \& Ryan, R. (1991). A motivational approach to self: Integration in personality. Perspectives on motivation. Vol. 38. P. 237-288.

Harre, R. (1983). Personal being. Oxford : Blackwell. 299 p.

Osgood, C. E., Suci, G. J., \& Tannenbaum, P. H. (1957). The measurement of meaning. Chicago and London : University of Illinois Press. 342 p.

\section{References}

Artemieva, E. Yu. (1980). Psikhologiia subektivnoi semantiki [Psychology of subjective semantics]. Moskva : Moskovskii gosudarstvennyi universitet [in Russian].

Ball, G. A. (1997). Psikhologicheskoie soderzhaniie lichnostnoi svobody: sushchnost i sostavliaiushchiie [Psychological content of personal freedom: essence and components]. Psikhologicheskii zhurnal-Psychological journal, 18 (5), 7-19 [in Russian].

Belova, A. S. (2008). Problema svobody v psikhologii: metodicheskii aspect [The problem of freedom in psychology: a methodological aspect].

(C) Medvedskaia Elena

DOI (article): https://doi.org/10.32626/2227-6246.2020-50.167-187 
DOI: https://doi.org/10.32626/2227-6246.2020-50

Pedagogika $i$ psikhologiia - Pedagogy and psychology, 1, 129-132 [in Russian].

Informatsionnoie obshchestvo $v$ Respublike Belarus. 2019 [Information society in the Republic of Belarus. 2019] (2019). Minsk : Natsionalnyi statisticheskii komitet Respubliki Belarus [in Russian].

Kuzmina, E. I. (1994). Psikhologiia svobody [Psychology of freedom]. Moskva : Moskovskii gosudarstvennyi universitet [in Russian].

Lanier, J. (2019). 10 argumentov udalit vse svoi akkaunty $v$ sotsialnykh setiakh [10 arguments to delete all your social media accounts]. Moskva : Eksmo [in Russian].

Leontiev, D. A. (2000). Psikhologiia svobody: k postanovke problemy samodeterminatsii lichnosti [Psychology of freedom: towards the problem of self-determination of a personality]. Psikhologicheskii zhurnal - Psychological journal, 21 (1), 15-25 [in Russian].

May, R. (2016). Chelovek $v$ poiskakh sebia [Man in search of himself]. Moskva : Institut obshchegumanitarnykh issledovanii [in Russian].

O'Reilly, T. (2018). Chto takoie Veb 2.0? [What is Web 2.0?]. Retrieved from http://www.computerra.ru/think/234100/ [in Russian].

Parizer, E. (2012). Za stenoi filtrov. Chto Internet skryvaiet ot vas? [Behind the filter wall. What is the Internet hiding from you? ]. Moskva : Alpina Biznes Buks [in Russian].

Petrenko, V. F. (2005). Osnovy psikhosemantiki [Basics of psychosemantics ]. Sankt-Peterburg : Piter [in Russian].

Frankl, V. (1990). Chelovek $v$ poiskakh smysla [A man in the search of sense]. Moskva : Progress [in Russian].

Fromm, E. (1990). Begstvo ot suobody [Escape from freedom]. Moskva : Progress [in Russian].

Shmelev, A. G. (1982). Ob ustoichivosti faktornoi struktury lichnostnogo semanticheskogo differentsiala [On the stability of the factor structure of the personal semantic differential]. Vestnik $M G U-M G U$ Vestnik, 14 (2), 62-65 [in Russian].

Bandura, A. (1997). Self-efficacy: the exercise of control. New York : W. H. Freeman \& Co.

Bentler, P. M., \& Lavoie, A. L. (1972). An Extension of semantic Space. Journal of Verbal Learning and Verbal Behaviour, 109, 123-144.

Deci, E., \& Ryan, R. (1991). A motivational approach to self: Integration in personality. Perspectives on motivation, 38, 237-288.

Harre, R. (1983). Personal being. Oxford : Blackwell.

Osgood, C. E., Suci, G. J., \& Tannenbaum, P. H. (1957). The measurement of meaning. Chicago and London : University of Illinois Press.

(C) Medvedskaia Elena

DOI (article): https://doi.org/10.32626/2227-6246.2020-50.167-187 
DOI: https://doi.org/10.32626/2227-6246.2020-50 2020. випуск 50

Медведская Єлєна. Категоризація поняття "свобода" представниками різних інформаційних субкультур

\section{АНОТАЦІЯ}

Мета статmі полягає в порівняльному аналізі структури і змісту поняття «свобода» у свідомості дорослих, які віддають перевагу різним індормаційним носіям: традиційним (друкованим) і новим (цифровим).

Методи. Дослідження проведено на статистично великій і гомогенній вибірці за віком, рівнем освіти і професійної діяльності (сфери розумової праці). Диференціацію респондентів на представників різних інформаційних субкультур здійснено на підставі двох критеріїв: 1) вибір інформаційної системи у вільний час (друкований носій або Інтернет); 2) час, що приділяється взаємодії із зазначеною системою. Критерії визначено за допомогою анонімного і добровільного анкетування. Для вивчення структури і змісту поняття "свобода» було використано авторський варіант методики семантичного диреренціала, що включає в себе дескриптори, раніше отримані іншими дослідниками як утворення семи категорій («оцінка», "сила», "активність», "складність», "упорядкованість», «реальність» і «звичайність») буденної свідомості.

Результати дослідження. Представлено результати порівняльного аналізу, проведеного в двох контрастних групах, які обирають різні інформаційні системи: суб'єктів читаючих і активних wеb-користувачів. Статистично достовірних відмінностей між двома вибірками не виявлено. У результаті первинної обробки даних усереднених оцінок за шкалами семантичного диференціала їх профрілі збігаються в різних групах. У результаті вторинної обробки (факторний аналіз) у представників різних інформаційних субкультур виявлено однакову когнітивну складність поняття «свобода» (12 факторів-категорій за критерієм Кайзера, з яких 4 невипадкові за своєю суб'єктивною значущістю для респондентів) $і$ близький зміст провідних категорій.

Висновки. Емпірично виявлено когнітивну простоту конструкту «свобода» в буденній свідомості дорослих білорусів і єдність представників різних інформаційних субкультур у його розумінні. Цю когнітивну спільність можна пояснити спільністю життєвого досвіду, який в ієрархії детермінант змісту свідомості виявляється більш значущим, ніж інфрормаційні звички, а, відтак, і сама інформація, незалежно від ії носія. Отримані дані частково розвіюють лякаючий міср про можливі швидкі

C Medvedskaia Elena

DOI (article): https://doi.org/10.32626/2227-6246.2020-50.167-187 
DOI: https://doi.org/10.32626/2227-6246.2020-50 2020. випуск 50

трансформації свідомості користувачів за допомогою цифрових технологій.

Ключові слова: свобода, буденна свідомість, категорії свідомості, когнітивна складність, семантичний диреренціал.

Медведская Елена. Категоризация понятия «свобода» представителями разных информационных субкультур

\section{АННОТАЦИЯ}

Цель статьи заключается в сравнительном анализе структуры и содержания понятия "свобода" в сознании взрослых, предпочитающих разные информационные носители: традиционные (печатные) и новые (цирровые).

Методы. Исследование проведено на статистически большой и гомогенной выборке по возрасту, уровню образования и профессиональной деятельности (сфреры умственного труда). Дифрреренциация респондентов на представителей разных информационных субкультур осуществлена на основании двух критериев: 1) выбор информационной системы в свободное время (печатный носитель или Интернет); 2) время, уделяемое взаимодействию с указанной системой. Критерии определены посредством анонимного и добровольного анкетирования. Для изучения структуры и содержания понятия «свобода» был использован авторский вариант методики семантического дирфреренциала, включающей в себя дескрипторы, ранее полученные другими исследователями как образующие семи категорий ("оценка», "сила», "активность», "сложность», «упорядоченность», "реальность» и «обычность») обыденного сознания.

Результаты исследования. Представлены результаты сравнительного анализа, проведенного в двух контрастных группах, выбирающих различные информационные системы: субъектов читающих и активных шеb-пользователей. Статистически достоверных различий между двумя выборками не обнаружено. В итоге первичной обработки данных усредненных оченок по шкалам семантического дифрреренциала их профили совпадают в разных группах. В результате вторичной обработки (факторный анализ) у представителей разных информационных субкультур выявлены одинаковая когнитивная сложность понятия «свобода» (12 факторов-категорий по критерию Кайзера, из которых (c) Medvedskaia Elena

DOI (article): https://doi.org/10.32626/2227-6246.2020-50.167-187 http://journals.uran.ua/index.php/2227-6246 
DOI: https://doi.org/10.32626/2227-6246.2020-50 2020. випуск 50

4 неслучайны по своей субъективной значимости для респондентов) и близкое содержание ведущих категорий.

Выводы. Эмпирически выявлены когнитивная простота конструкта "свобода» в обыденном сознании взрослых белорусов и единство представителей различных информационных субкультур в его понимании. Эту когнитивную общность можно объяснить общностью жизненного опыта, который в иерархии детерминант содержания сознания оказывается более значимым, чем информационные привычки, а, значит, и сама информация, независимо от ее носителя. Полученные данные частично развеивают пугающий миф о возможных быстрых трансформациях сознания пользователей посредством цифровых технологий.

Ключевые слова: свобода, обыденное сознание, категории сознания, когнитивная сложность, семантический дифференциал.

Original manuscript received September 02, 2020 Revised manuscript accepted October 07, 2020 